\title{
PROBLEM BASED LEARNING (PBL) AND VERBAL-VISUAL ABILITIES: ITS INFLUENCE ON STUDENTS' MATHEMATICS LEARNING OUTCOMES
}

\author{
Pengki Yudistira $^{1^{*}}$, Syaiful $^{2}$, Evita Anggareini $^{3}$ \\ ${ }^{1,2,3}$ Department of Mathematics Education, Postgraduate Program, Universitas Jambi, Indonesia \\ *Corresponding author: pengkiyudistira27@gmail.com
}

\begin{tabular}{|c|c|}
\hline Article Info & ABSTRACT \\
\hline Article history: & This quasi-experiment aims to determine the influence of the \\
\hline Received: April 1, 2020 & $\begin{array}{l}\text { Problem Based Learning (PBL) model and verbal-visual abilities } \\
\text { on Grade VIII students' learning outcomes. The population in this }\end{array}$ \\
\hline Accepted: July 20, 2020 & study were all students of SMPN 7 Kerinci and the sample of the \\
\hline Published: July 31, 2020 & $\begin{array}{l}\text { study was } 27 \text { students from class VIII A as the experimental class } \\
\text { and } 26 \text { students from class VIII B as the control class. Research }\end{array}$ \\
\hline Keywords: & data collection through test instruments to see students' \\
\hline $\begin{array}{l}\text { Learning outcomes } \\
\text { Problem Based Learning (PBL) } \\
\text { model } \\
\text { Verbal-visual ability }\end{array}$ & $\begin{array}{l}\text { ANOVA with SPSS } 21 \text { software with a significance of } 0.05 \text {. The } \\
\text { results showed that there was an influence of the Problem Based } \\
\text { Learning (PBL) model and verbal-visual ability on the mathematics } \\
\text { learning outcomes of Grade VIII students with sig. } 0,001<0,005 \text {, } \\
\text { there is an influence of verbal-visual ability on mathematics } \\
\text { learning outcomes of class VIII students with sig. } 0,000<0.05 \text { and } \\
\text { there is no interaction between the PBL model and verbal-visual } \\
\text { ability in influencing students' learning outcomes in class VIII with } \\
\text { sig. } 0.341>0.05 \text {. }\end{array}$ \\
\hline
\end{tabular}

\section{PROBLEM BASED LEARNING (PBL) DAN KEMAMPUAN VERBAL-VISUAL: PENGARUHNYA TERHADAP HASIL BELAJAR MATEMATIKA ABSTRAK}

\section{Kata Kunci:}

Hasil belajar

Model Problem Based Learning (PBL)

Kemampuan verbal-visual

\begin{abstract}
Quasi eksperimen ini bertujuan untuk mengetahui pengaruh model Problem Based Learning (PBL) dan kemampuan verbal-visual terhadap hasil belajar matematika sisiwa kelas VIII. Populasi dalam penelitian ini adalah seluruh siswa SMP Negeri 7 Kerinci dan menjadi sampel penelitian adalah 27 siswa kelas VIII A sebegai kelas eksperiment dan 26 siswa kelas VIII B sebagai kelas kontrol. Pengumpulan data dilakukan dengan menggunakan intrumen soal tes untuk melihat hasil belajar matematika siswa. Analisis uji statistik menggunakan anova dua jalur dengan SPSS softwere 21 taraf kepercayaan 0,05 . Hasil penelitian menunjukkan bahwa terdapat pengaruh model Problem based learning (PBL) dan kemampuan verbal-visual terhadap hasil belajar matematika siswa kelas VIII dengan sig. $0,001<0,005$, terdapat pengaruh kemampuan verbal-visual terhadap hasil belajar matematika siswa kelas VIII dengan sig. 0,000 $<0,05$ dan tidak terdapat interaksi antara model PBL dengan kemampuan verbal-visual dalam mempengaruhi hasil belajar siswa kelas VIII dengan sig. 0,341>0,05.
\end{abstract}




\section{INTRODUCTION}

The process of learning mathematics by students is a students' effort to gain knowledge about mathematics. In the process of learning mathematics students are given the opportunity to construct their own knowledge. Because the role of mathematics is very important in building the basis of logic or quantitative reasoning that can be used for other lessons [1]. Besides, students can also play an important role in representing, communicating and predicting solutions in mathematics learning.

Students are one of the main actors in the learning process, the fundamental factors possessed by students are verbal and visual abilities. As explained by Stephen Reed that verbal is knowledge that is expressed through language while visual is spatial knowledge that is stored in the form of images [2]. Verbal-visual skills will help students understand and solve mathematical problems, especially essay questions. The better or higher the students' verbal abilities, the better the students' abilities in completing essay questions [3].

Activities or processes by each student in solving problems certainly cannot be separated from the way students capture and process the information they received. Verbal abilities will help students understand the meaning of a theory and make mathematical models to solve mathematical problems [4]-[6], thus, visual abilities can help stimulate metacognitive processes such as regulating how to observe, see, pay attention, imagine, estimate or assess a problem [7]-[9].

Ideas in mathematics are often interpreted through visual symbols and verbal symbols. Interpretation can be in the form of words or verbal, written, pictured, tables, graphs, concrete objects, and other mathematical symbols [10]. Many textbooks connect the verbal component to the visual or vice versa. Visual symbols and verbal symbols can be used together or separately in mathematics. For example, we find a diagram with an explanation, trigonometric calculations and curves and their calculations. So, with verbalvisual abilities students can get good or complete learning outcomes. But in reality, in the process of learning mathematics, teachers rarely pay attention to the fundamental abilities (verbal and visual abilities) of a student. This can be seen when they are given practice questions in the verbal form or in the form of real problems. Only a small part of students work on it while others only wait for answers from friends or the teacher's explanation and then copy it [3].

Based on observation in one of state junior high schools in Jambi and researcher's experience teaching in private junior high school in Jambi, the researchers found that in the process of learning mathematics, teachers often give formula directly to students without giving an explanation about the basic concept of the formula, so students know the formula earlier but do not understand the use and cannot even solve a problem with the formula. The school only has one mathematics teacher each who teaches classes VII, VIII, and IX. This is also reinforced by the students' explanation that they often find problems in solving assignments and tests related to the concept of daily life which results in poor students learning outcomes. Researcher did interview with several students and they said that they had difficulty applying story-based or verbal questions into the form of mathematical symbols, images, graphics and also difficult to explain the elements of variables, lines, pictures with words related to the context of everyday life.

This has an impact on student learning outcomes that are not as expected. This is proven from the result of the 2nd semester mathematics exam in the SMP Negeri (State Junior High School) for the last 2 years with an average percentage of students who completed 53\% and students who did not complete with a percentage of $47 \%$, the standard score applied at the school is 70. Whereas in private SMP with accreditation A (ranking),

154 Indonesian Journal of Science and Mathematics Education ( I J S M E ) 
it has an average score far from the standard score (75), with an average percentage of $45 \%$ of students passing the standard, and 55\% of students not meeting the standard. And to overcome this problem, remedial measures are taken. So, it can be concluded that students' learning outcomes in this junior high school did not reach the standard, because s Junior High school was declared to have reached the standard if $75 \%$ of students pass the score standard.

The problem of learning outcomes occurs due to several factors, apart from the inner factors of students, there are other factors such as the learning model. Therefore, teachers are required to be able to choose learning models that can stimulate the enthusiasm of each student to actively engage in their learning experiences [11]. This is a challenge for mathematics teachers to eliminate tedious learning by presenting mathematical materials in a fun way and increase the enthusiasm of students to be more motivated to learn mathematics [12].

Along with the development of cognitive psychology, evaluation of learning outcomes is also developing, especially for the cognitive domain. Now, in evaluating the achievement of learning outcomes, teachers only assess cognitive goal (outcome) without considering cognitive process (learning process/process of gaining knowledge), especially metacognitive knowledge and metacognitive skill [13]. So, to make learning run well, we try to apply a learning model that can make the process of learning mathematics dominated by student activities, by bringing mathematics closer to the students' environment or students' daily activities, so students will understand mathematical concepts properly. One learning model that can achieve this is the PBL (Problem Based Learning) model. Many research results showed that problem-based learning is a student-centered learning approach that is able to stimulate student thinking skill [14].

The use of Problem Based Learning learning models in the learning process will make student activities more dominant, students will not only 'remember' theories but also master the concepts, fully understand and be able to solve mathematical problems themselves. Problem Based Learning is a learning model that uses problems as a focus for developing problem solving skills and self-regulation [15]-[17].

PBL steps are 1) Orienting students to problems, 2) Organizing students to learn, 3) Guiding individual/group learning experiences, 4) Developing and presenting students work, 5) Analyzing and evaluating problem solving processes [18]-[23]. Thus, student activities in learning mathematics with PBL model are driven by their curiosity and understanding of mathematical concepts. Understanding of mathematical concepts to solve problems is the visual and verbal abilities of students. This condition illustrates that performance assessment in problem based learning is very influential on the achievement and improvement of students' mathematical problem solving skills [24].

The success of learning depends on student learning outcomes. Learning outcomes are the most important part of the learning process as a measure of learning success. Students' learning outcomes are interpreted as changes in behavior in students. This means that learning outcomes include cognitive, affective and psychomotor aspects. Learning outcomes are revealed from the evaluation of learning which not only depends on what the teacher presents, but is also influenced by the results of interactions between various information, and how students process information based on their initial understanding [12].

Many researches have shown that both PBL model and verbal-visual abilities can improve student learning outcomes. As Yeyen Sayekti revealed in her research that Problem Based Learning can improve students' concept understanding [25], also revealed by Cut Eka Parasmya and Agus Wahyuni in their research, that the application of the 
Problem Based Learning model can improve students' learning outcomes [26]. And Fergi Fzaijza Fatri's research proved that the cognitive style of the Visualizer and Verbalizer influences students' mathematical representation abilities [27]. Although there are many studies that prove that PBL model and verbal-visual ability have a positive impact on learning outcomes, but there is no research that collaborates PBL model and verbal-visual abilities, this research will fill this gap and see the effect of PBL model and verbal-visual abilities on mathematics learning outcomes, and also see the interaction between PBL model and verbal-visual abilities in improving students' mathematics learning outcomes. In this research, we focus on one domain of learning outcomes, the cognitive domain. So, this research is expected to be one of the references for teachers or other researchers who are trying to improve student learning outcomes.

\section{METHOD}

This study was a quasi-experimental research [28]. Research design is a way of collecting data and analyzing data that is used as a guide in conducting research [29]. Figure 1 below shows the research design created by the researcher.

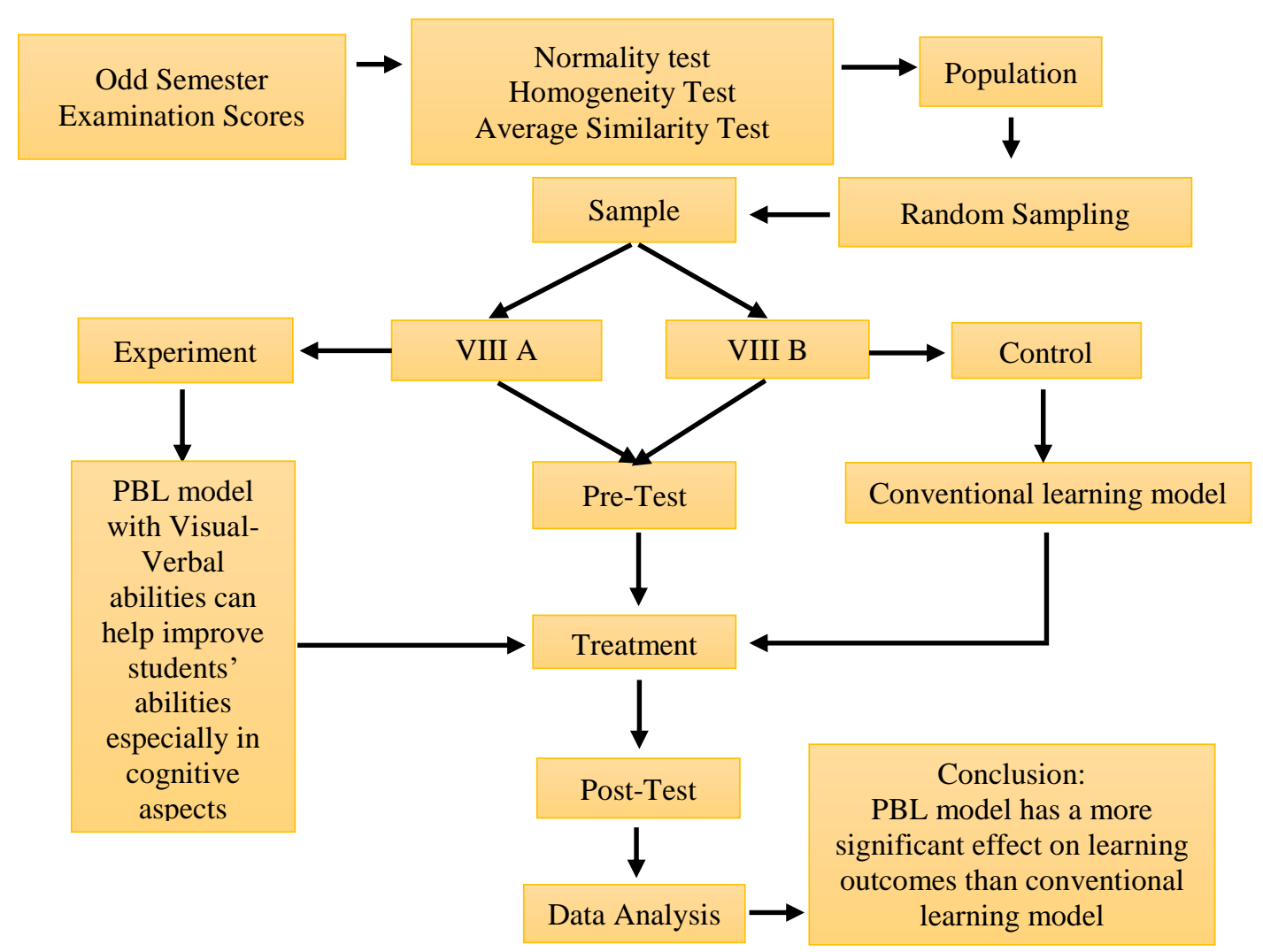

Figure 1. Research Procedure

This research was conducted in the even semester in class VIII of SMP Negeri 7 Kerinci, Jambi, Indonesia, with a quasi-experimental method using a $2 \times 2$ factorial design, so this research was conducted in two sample classes, one as an experimental class and one as a control class. For the selection of sample classes, a random sampling technique was used, the study was conducted for six meetings. In the experimental class (VIII A), we applied the Problem Based Learning (PBL) learning model in the learning process, and the 
control class (VIII B) used the learning model commonly used by the teacher in the school, which in this study was called as "the conventional learning model".

Before conducting research, researchers test for normality, homogeneity and average similarity in odd semester exam scores. Normality test is conducted to determine the normality of the population to meet the parametric statistical analysis requirements. This quasi-experimental research is carried out with some procedures: identifying problems, formulating problems, and studying literature, which then produces research tools in the form of lesson plans and research instruments in the form of essay tests that include cognitive knowledge (C1), understanding (C2), applications (C3), analysis (C4), synthesis (C5), and evaluation (C6). This research tool has passed the validation test by experts (competent education experts). Hypothesis testing in this study uses the F test which aims to prove the truth of the hypothesis. Hypothesis testing is done using two-way ANOVA.

\section{RESULTS AND DISCUSSION}

This research lasted for 3 weeks, beginning with giving pre-test to the sample students and ending with giving post-test. Test questions used in pre-test and post-test are questions that have passed the instrument feasibility test. Here we attach essay questions along with student answers and analysis of students' answers. The students' answers presented were from students who received the highest scores in the experimental and control classes, and the lowest scores in the experimental and control classes.

Table 1. Instrument Questions and Answers from Experimental and Control Class Students

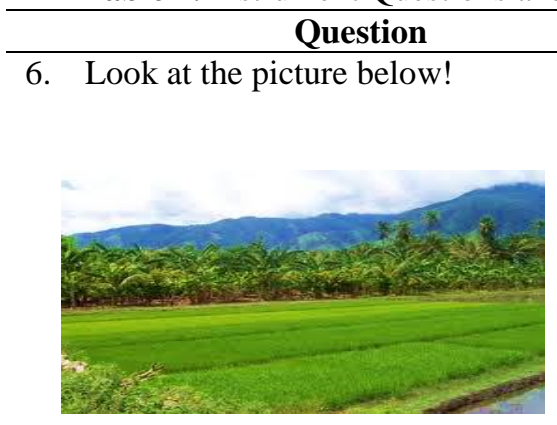

Ali has a rectangular rice field with a length of 20 meters and a width of 15 meters. Ali will make a paddy field in one of the diagonal sides and then plant it with chili trees. If the distance between trees is half a meter and the price of one chilli seed is Rp. 2,000, - how much does it cost to buy chilli trees to plant? Sketch out the shape of the paddy field and count it!

\section{Answer}

From the picture of Ali's rice field, we can see that the rice field is rectangular in shape with a length of $20 \mathrm{~m}$ and a width of $15 \mathrm{~m}$. From the rectangle, there is a diagonal that will be used to plant chilies. So, the sketch of the rice field will be:

20

15

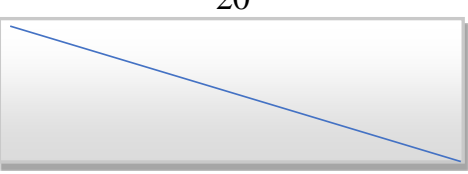

First we must find the length of the diagonal side by using the Pythagoras formula.

If the length is $\mathrm{P}$, the width is $\mathrm{L}$, and the diagonal side is $\mathrm{X}$. Then, the pythagoras formula is:

$\mathrm{X}^{2}=\mathrm{P}^{2}+\mathrm{L}^{2}$

$X^{2}=20^{2}+15^{2}$

$X^{2}=400+225$

$\mathrm{X}=\sqrt{625}$

$X=25$, Then the diagonal length of the paddy field is $25 \mathrm{~m}$.

Because the distance between the chilli plants is half a meter, so the diagonal length of the paddy field is $\frac{25 \mathrm{~m}}{0,5 \mathrm{~m}}=50$ chilli seeds that can be planted. If the price of one chili seedlings is Rp. 2000, then the capital of purchasing seeds amounted to $50 \times \operatorname{Rp} 2000=$ Rp. 100.000 .

So the cost to buy chili seeds is Rp. 100,000 


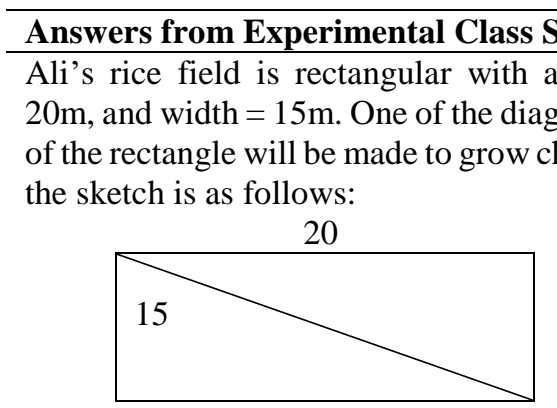

On the diagonal side of the rice fields as in the sketch, Ali wants to plant chillies, so, first we have to find the length of the diagonal side by using the Pythagoras formula. If length is A, width is B, and diagonal is $\mathrm{C}$, then the pythagoras formula is:

$\mathrm{C}^{2}=\mathrm{A}^{2}+\mathrm{B}^{2}$

$\mathrm{D}^{2}=20^{2}+15^{2}$

$\mathrm{D}^{2}=400+225$

$\mathrm{D}=\sqrt{\mathbf{6 2 5}}$

$\mathrm{D}=25$, Then the diagonal length of the paddy field is $25 \mathrm{~m}$.

Because the planting distance between chillies is half a meter, the diagonal length of the rice field bund is $25 \mathrm{~m}$ divided by $0.5 \mathrm{~m}$, so that 50 chilli seeds can be planted. The price of one chili seedlings is Rp. 2000, then the capital of purchasing seeds amounted to $50 \times \mathrm{Rp} .2000=$ Rp. 100.000

So, the cost needed to buy seeds is Rp. 100.000

\section{Answers from Control Class Students}

The rectangle has a length of $20 \mathrm{~m}$ and a width of $15 \mathrm{~m}$. There is one diagonal side made for growing chillies.

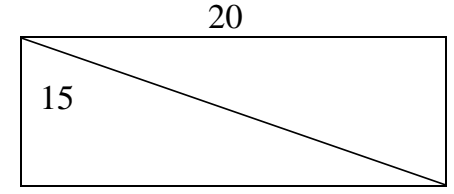

If :

$$
\begin{aligned}
& \text { L = Length } \\
& \text { W = Width } \\
& D=\text { Diagonal }
\end{aligned}
$$

Pythagoras formula as follows:

$$
\begin{aligned}
& \mathrm{D}^{2}=\mathrm{L}^{2}+\mathrm{W}^{2} \\
& \mathrm{D}^{2}=20^{2}+15^{2} \\
& \mathrm{D}^{2}=400+225 \\
& \mathrm{D}=\sqrt{625} \\
& \mathrm{D}=25,
\end{aligned}
$$

The distance to plant chili is half a meter, so the length of the diagonal of the rice fields is $\frac{25 \mathrm{~m}}{0,5 \mathrm{~m}}=$ 50 chilli seeds. The price of one chilli seedlings is Rp. 2,000

Capital to buy seeds is $50 \times \mathrm{Rp} 2000=\mathrm{Rp}$ 100.000

So the cost to buy seeds is Rp. 100,000

Here is presented the calculation data of the final test results of the eighth-grade students of SMP Negeri 7 Kerinci.

Table 2. Students' Mathematics Learning Outcomes (Experimental Class and Control Class)

\begin{tabular}{clcc}
\hline \multirow{2}{*}{ No } & \multicolumn{1}{c}{ Statistic } & \multicolumn{2}{c}{ Class } \\
\cline { 3 - 4 } & Experimental & Control \\
\hline 1 & Number of & 27 & 26 \\
& Sample (N) & & \\
2 & Average & 70,56 & 62,50 \\
3 & Standard Error & 2,27 & 1,72 \\
& Mean & & \\
4 & Median & 70 & 65 \\
5 & Modus & 75 & 70 \\
6 & Standard & 12,35 & 8,75 \\
& Deviation & & \\
7 & Varians & 152,564 & 76,500 \\
8 & Maximum & 95 & 75 \\
9 & Minimum & 50 & 45 \\
10 & Range & 45 & 30 \\
11 & Slope & 0,34 & $-0,36$ \\
12 & Slope Standard & 0,45 & 0,46 \\
& Error & & \\
13 & Kurtosis & $-0,34$ & $-0,87$ \\
14 & Kurtosis standard & 0,872 & 0,89 \\
& Error & & \\
\hline
\end{tabular}


Table 3 will show the results of hypothesis testing with a significance level of $5 \%$ or 0,05 which will be compared with the significance value in the table. If sig. $>0,05$, it is concluded that $\mathrm{H}_{0}$ is accepted and if sig. $<0,05$, it was concluded that $\mathrm{H}_{1}$ is accepted. The results of the data analysis use the Two Way Anava analysis is presented in Table 3.

Table 3. Two Way Anava Test Calculation Results

\begin{tabular}{ccc}
\hline \multicolumn{3}{c}{ Tests of Between-Subjects Effects } \\
\hline Dependent Variable: & Learning Outcomes \\
Source & $\mathrm{F}$ & Sig. \\
Corrected Model & 91,384 &, 000 \\
Intercept & 3482,512 &, 000 \\
Class & 12,219 &, 001 \\
Ability & 220,685 &, 000 \\
Class * Ability & 1,083 &, 341 \\
\hline
\end{tabular}

Based on table 2 above, the value of sig. for class variables (experimental and control) is 0.001 , the value is smaller than the significance level of 0.05 , it can be concluded that $\mathrm{HO}$ is rejected, that is, there is an influence of Problem Based Learning (PBL) models on student mathematics learning outcomes. The results of this study are in accordance with the research hypothesis. The learning process using the PBL model is considered appropriate because this model uses problems as a focus for developing problem solving skills, material, and self-regulation [15].

Previous study has revealed the same results, that the learning outcomes of students who learn with PBL model are higher than the learning outcomes of students who learn with the demonstration learning method [30]. On the other hand, previous study has revealed that there is no effect of visual-spatial intelligence on mathematics learning outcomes in PBL [31]. There are several factors from teachers or students that must be considered if we want to use the PBL model.

Important factors that must be considered by teachers in using the PBL model are the teacher must be able to manage the class well, ensure students are ready to learn, divide students with different abilities in one group, use learning time well, and make good lesson plans. While the factors that must be prepared from students are students must be accustomed to finding information both from books and from friends, in one group, students with high intelligence abilities must help students with lower intelligence, and students should not feel ashamed to express opinions. If these factors are not met, then PBL models may not affect students' learning outcomes.

Because of the application of PBL, students are accustomed to practicing their abilities in analyzing symbols, grammar, communication skills, interpreting, using knowledge and creating with the guidance of the teacher, so that it influences student learning outcomes in mathematics. Silfanus and Valeria have analyzed the understanding of verbal to visual translation on trigonometric material. The results of this study indicate that most mathematics education students are still in the medium category, or in other words they have the ability to understand verbal to visual translation, but it is not perfect [32]. Whereas this study shows that there is an influence of verbal-visual ability on student mathematics learning outcomes, this can be seen in the 'ability' variable in Table 3, there is a significance value that is smaller than the significant level that is $0,000<0,05$. Then it can be concluded that $\mathrm{H}_{0}$ is rejected or there is an influence of verbal-visual ability on students' mathematics learning outcomes.

Furthermore, based on the results of data analysis, there is no interaction between PBL learning models with Verbal-Visual abilities, this can be seen from the significance 
value of the class * ability variable, which is 0,341 while the significant level is 0,05 , so that $0,341>0,05$. So, it can be concluded that $\mathrm{H} 0$ is accepted and $\mathrm{H} 1$ is rejected or there is no interaction between PBL learning model and Verbal-Visual ability on mathematics learning outcomes of Grade VIII students of SMP Negeri 7 Kerinci.

To compare the results of the pre-test with the post-test, in this study we used the $\mathrm{N}$ Gain test. N-Gain is used to find out the improvement of students' abilities between before and after treatment. The N-Gain Test has a level of interpretation that refers to the N-Gain score. For high interpretation, $\mathrm{N}$-Gain score $\geq 0,70$, for moderate interpretation, score between $0,30 \leq \mathrm{N}$-Gain $<0$, 0 , and for low interpretation, $\mathrm{N}$-Gain score $<0,30$

Table 4. N-Gain Test Results

\begin{tabular}{cccc}
\hline No & Class & $\begin{array}{c}\text { N-Gain } \\
\text { Results }\end{array}$ & Interpretation \\
\hline 1 & Experimental & 0,35 & Medium \\
2 & Control & 0,34 & Medium \\
\hline
\end{tabular}

Based on table 3 above, the results of the N-Gain test show that the experimental class gained 0.35 with a medium interpretation. $\mathrm{N}$-Gain results for the control class gained 0.34 with medium interpretation. The average value of the pre-test and post-test sample classes will be presented in the table below.

Table 5. Average Score of Pre-test and Post-test Results

\begin{tabular}{cccc}
\hline Group & Pre-test & Treatment & Post-test \\
\hline Experimental & 57,41 & PBL & 70,56 \\
Control & 55,96 & Control & 62,50 \\
\hline
\end{tabular}

Based on the results of this research, it is clear that the results of learning mathematics using the PBL model (experimental class) get better results. In other words, PBL learning models are proven to be well applied in mathematics learning for students who have verbal-visual abilities. If comparing the scores of the experimental class with the scores of the control class it is seen that the increase in scores in the experimental class is greater, so the effect of the PBL model is greater than the conventional learning model. The steps of the PBL model combined with the use of verbal-visual abilities are described in the table below.

Table 6. Learning Steps

\begin{tabular}{|c|c|c|}
\hline Steps & Teacher Activities & Student activities \\
\hline $\begin{array}{l}\text { Step } 1 \\
\text { Stimulation/Indentify } \\
\text { the problem }\end{array}$ & $\begin{array}{l}\text { The teacher divides } \\
\text { students into several } \\
\text { groups and explains } \\
\text { learning objectives, } \\
\text { provides motivation to } \\
\text { focus students' attention } \\
\text { on the learning topic, } \\
\text { shows a picture related to } \\
\text { the learning topic, } \\
\text { conducts } \\
\text { demonstration, and tells } \\
\text { an incident related to the } \\
\text { learning topic to raise a } \\
\text { problem. }\end{array}$ & $\begin{array}{l}>\text { Students pay attention to the teacher's } \\
\text { explanation and observe the picture in the } \\
\text { student textbook about the Pythagorean } \\
\text { theorem } \\
>\text { Students observe and understand the pictures } \\
\text { contained in the book }\end{array}$ \\
\hline
\end{tabular}


Step 2

Identify the problem and formulate a hypothesis

Step 3

Data collection

Step 4

Data Processing

Step 5

Evaluation

Step 6

Drawing Conclusion
The teacher gives the opportunity for students to analyze and identify questions related to the picture and provide verbal explanation through learning activities.

The teacher gives instructions to students to gather relevant information from various sources to support learning activities and to answer questions that appear verbally and visually that have been identified through learning activities.

The teacher encourages students to discuss and process observational data by explaining images (visual) verbally and describe verbal questions into visual form.

The teacher encourages students to discuss the results of their observations, and verify the observations with data or theories in the source book. The teacher also guides and explains ways to prove the truth of the observations. Then the teacher verifies the final results of observations from students.

The teacher helps students to discuss in order to conclude the observations so that the learning outcomes are in accordance with the learning objectives.
Students read explanations and analyze concepts from various sources related to the Pythagorean theorem

Students listen to an explanation of the truth of the Pythagorean theorem

Students understand the lesson being observed or ask questions to get additional information (starting from factual questions, environmental problems, to hypothetical questions) to develop creativity, curiosity, the ability to formulate questions, and the ability to analyze verbally and visually.

Students observe images, gather information, and collect data obtained from various sources about the Pythagorean theorem to answer questions that come from themselves.

Students explore their knowledge by reading reference books and trying to understand sample problems in textbooks about the Pythagorean theorem.

Students discuss to process observational data in the form of images with verbal explanations, and process verbal information by describing it visually. Students try to process information, observe and understand it, and make decisions together.

Students and teachers together discuss the results of the analysis of each group.

Group representatives explain their observations verbally and provide visual images to other groups. The other group was given the opportunity to ask questions about the group's observations.

$>$ The teacher verifies students' observations and students evaluate their observations.

Students discuss to conclude and convey the results of the discussion verbally, in writing, or visual images.

Do a question and answer about the results of the analysis of each group.

The teacher helps students to conclude important points that appear in learning. 


\section{CONCLUSION}

Based on the results of this research, it can be concluded that there is a significant effect of the application of PBL learning models and Verbal-Visual abilities on student mathematics learning outcomes. Verbal-Visual Ability also has a significant effect on student mathematics learning outcomes. However, there was no interaction between PBL learning model and Verbal-Visual ability on the mathematics learning outcomes of Grade VIII students in SMP Negeri 7 Kerinci.

\section{REFERENCES}

[1] R. Alpian and Bambang Sri Anggoro, "Students' mathematical reasoning analysis based on van hiele theory," Indones. J. Sci. Math. Educ., vol. 03, no. March, pp. 96105, 2020.

[2] Steven k Reed, kognisi teori dan aplikasi. Jakarta: Selamba Humanika, 2011.

[3] Wahyuddin, "Analisis Kemampuan Menyelesaikan Soal Cerita Matematika Ditinjau Dari Kemampuan Verbal," BETA J. tadris Mat., vol. 2, no. 2, pp. 148-160, 2016.

[4] N. A. Daniyati and Sugiman, "Hubungan Antara Kemampuan Verbal, Kemampuan Interpersonal, dan Minat Belajar dengan Prestasi Belajar Matematika," Pythagoras J. Pendidik. Mat., vol. 10, no. 1, pp. 50-60, 2015.

[5] A. Saregar and W. Sunarno, "Eksperimen Dan Demonstrasi Diskusi Menggunakan Multimedia Interktif Ditinjau Dari Sikap Ilmiah Dan Kemampuan Verbal Siswa," J. Inq., vol. 2, no. 2, pp. 100-113, 2013.

[6] G. R. Yuwono, I. ketut Mahardika, and A. A. Gani, "Pengaruh Model Pembelajaran Inkuiri Terbimbing terhadap Hasil Belajar Fisika Siswa (Kemampuan Representasi Verbal, Gambar, Matematis, dan Grafik) di SMA," J. Pembelajaran Fis., vol. 5, no. 1, pp. 60-65, 2016.

[7] S. N. P.B, "Menghadapi Generasi Visual: Literasi Visual untuk Menstimulasi Kemampuan Berpikir dalam Proses Pembelajaran," ELSE (Elementary Sch. Educ. Journal) J. Pendidik. dan Pembelajaran Sekol. Dasar, vol. 1, no. 2a, pp. 48-59, 2017.

[8] R. Sundayana, "Kaitan antara Gaya Belajar, Kemandirian Belajar, dan Kemampuan Pemecahan Masalah Siswa SMP dalam Pelajaran Matematika," Mosharafa J. Pendidik. Mat., vol. 5, no. 2, pp. 75-84, 2018.

[9] M. A. R. Meli Mardiana Patath, Bety Miliyawati, "Meningkatkan Kemampuan Berpikir Kritis Matematis dengan Model Pembelajaran VAK ( Visualization Auditory Kinestetic) dan Dampaknya Terhadap Motivasi Belajar Siswa SMA," J. Ilm. FKIP Univ. Subang, vol. 4, no. 2, p. 170, 2018.

[10] M. Sabirin, "Representasi dalam Pembelajaran Matematika," JPM IAIN Antasari, vol. 1, no. July, pp. 33-44, 2019.

[11] Rusman, model-model pembelajaran mengembangkan profesionalisme guru edisi ke dua. jakarta: Rajawali pers, 2014.

[12] A. Irawan and G. Kencanawaty, "Peranan Kemampuan Verbal Dan Kemampuan Numerik Terhadap Kemampuan Berpikir Kritis Matematika," AKSIOMA J. Math. Educ., vol. 5, no. 2, pp. 110-119, 2017.

[13] Syaiful, "Metakognisi Siswa dalam Pembelajaran Matematika Realistik di Sekolah Menengah Pertama," Edumatica, vol. 01, no. 02, pp. 1-13, 2011.

[14] N. Mustaffa, Z. Ismail, Z. Tasir, and M. N. H. M. Said, "The Impacts of Implementing Problem-Based Learning (PBL) in Mathematics: A Review of Literature," Int. J. Acad. Res. Bus. Soc. Sci., vol. 6, no. 12, 2016. 
[15] P. Eggen and D. Kouchak, strategi dan model pembelajaran. jakarta: PT. indeks, 2012.

[16] C. Anwar et al., "Effect Size Test of Learning Model Arias and PBL: Concept Mastery of Temperature and Heat on Senior High School Students," Eurasia J. Math. Sci. Technol. Educ., vol. 15, no. 3, 2019.

[17] V. B. Gómez-Pablos, M. M. del Pozo, and A. G.-V. Muñoz-Repiso, "Project-based learning (PBL) through the incorporation of digital technologies: An evaluation based on the experience of serving teachers," Comput. Human Behav., vol. 68, pp. 501-512, 2017.

[18] N. W. Ashari and Salwah, "Problem Based Learning (PBL) dalam Meningkatkan Kecakapan Pembuktian Matematis Mahasiswa Calon Guru," J. Mat. dan Pendidik. Mat., vol. 2, no. 2, pp. 100-109, 2017.

[19] H. B. Clausen and V. Andersson, "Problem-based Learning, Education and Employability: A Case Study with Master's Students from Aalborg University, Denmark," J. Teach. Travel Tour., vol. 19, no. 2, pp. 126-139, 2019.

[20] D. Kokotsaki, V. Menzies, and A. Wiggins, "Project-based learning: A review of the literature," Improv. Sch., vol. 19, no. 3, pp. 267-277, 2016.

[21] C. Anwar, "The Effectiveness of Problem Based Learning Integrated With Islamic Values Based on ICT on Higher Order Thinking Skill and Students' Character," AlTa lim J., vol. 23, no. 3, p. 224, 2017.

[22] Y. Yuliana and F. Firmansah, "The Effectiveness of Problem-Based Learning With Social Media Assistance To Improve Students' Understanding Toward Statistics," Infin. J., vol. 7, no. 2, p. 97, 2018.

[23] R. R. T. Wasonowati, T. Redjeki, and S. R. D. Ariani, "Penerapan Model Problem Based Learning (PBL) pada Pembelajaran Hukum-Hukum Dasar Kimia Ditinjau dari Aktivitas dan Hasil Belajar Siswa Kelas X IPA SMA Negeri 2 Surakarta Tahun Pelajaran 2013/2014," J. Pendidik. Kim., vol. 3, no. 3, pp. 66-75, 2014.

[24] R. Sugiarni, E. Alghifari, and A. R. Ifanda, "Meningkatkan Kemampuan Spasial Matematis Siswa dengan Model Pembelajaran Problem Based Learning berbantuan geogebra," KALAMATIKA J. Pendidik. Mat. Vol., vol. 3, no. 1, pp. 93-102, 2018.

[25] Y. Sayekti, "Pengaruh Problem Based Learning dengan Strategi 'MURDER ‘ terhadap Kemampuan Pemahaman Konsep Matematis Siswa," AlphaMath J. Math. Educ., vol. 5, no. 1, pp. 24-32, 2019.

[26] C. E. Parasamya and A. Wahyuni, "Upaya Peningkatan Hasil Belajar Fisika Siswa melalui Penerapan Model Pembelajaran Problem Based Learning (PBL)," J. Ilm. Mhs., vol. 2, no. 1, pp. 42-49, 2017.

[27] F. F. Fatri, M. Maison, and S. Syaiful, "Kemampuan Representasi Matematis Siswa Kelas VIII SMP Ditinjau dari Gaya Kognitif Visualizer dan Verbalizer," J. Didakt. Mat., vol. 6, no. 2, pp. 98-111, 2019.

[28] Y. Rafika, W. Anggraini, and R. El Fiah, "Perbandingan Model Pembelajaran Mind Mapping dan ARIAS (Assurance, relevance, Interest, Assessment, Satisfaction) terhadap Pemahaman Konsep Fisika," Indones. J. Sci. Math. Educ., vol. 02, no. 2, pp. 210-216, 2019.

[29] D. Gede, A. Putra, I. W. P. Astawa, and I. M. Ardana, "Pengaruh model pembelajaran blended learning terhadap pemahaman konsep dan kelancaran prosedur matematis," J. Ris. Pendidik. Mat., vol. 6, no. 1, pp. 75-86, 2019.

[30] B. Wulandari and H. D. Surjono, "Pengaruh Problem-Based Learning terhadap Hasil Belajar ditinjau dari motivasi belajar PLC di SMK," J. Pendidik. Vokasi, vol. 3, no. 2, pp. 178-191, 2003. 
[31] M. M. Sulistyarini and F. G. I. Santoso, "Pengaruh Kecerdasan Visual-Spasial terhadap Hasil Belajar Matematika dalam Problem Based Learning pada Siswa SMA Kelas x," J. Ilm. Edukasi Mat., vol. 1, no. 1, pp. 56-72, 2015.

[32] S. Jelatu and V. S. Kurnila, "Analysis of Translation Understanding from Verbal to Visual on Trigonometry Concept," Form. J. Ilm. Pendidik. MIPA, vol. 9, no. 3, pp. 191-202, 2019. 